\title{
MOTIVASI KERJA STAF SANGGAR KEGIATAN BELAJAR (SKB) LUBUK BEGALUNG KOTA PADANG
}

\begin{abstract}
Nova Devista*
Abstract

The working motivation is a very crucial factor in accomplishing the goal of the Centre for Learning Activities program. It is influenced by various internal factors as well as external factors. This study was aimed at disclosing the working motivation of the staff at the Centre for Learning Activities in Lubuk Begalung, and finding out factors influencing the working motivation and efforts that have been practiced by the headmaster to solve various problems.

A qualitative approach was utilized to answer the research problems. Data were collected by means of observation, interviews and documentation studies. The main resource person was the headmaster and expanded by a snowball technique. The data were analyzed by techniques as suggested by Miles and Huberman (1992) which consist of data reduction, presentation and drawing conclusions. Validation of data was conducted through triangulation, lengthening the observation and discussion with colleagues.

The findings of this study are : (1) the working motivation of the staff of the Centre for Learning Activities is categorized as less satisfactory (2) the working motivation of the staff is influenced by many factors, such as unfavorable working climate, leadership style of the headmaster and uncertainty of reward system, and (3) some efforts that have been practiced by the headmaster are allowing the staff to get advanced degree, directing the staff and warning the staff with low achievement. It is strongly recommended to do more activities and programs to improve the working motivation of the staff.
\end{abstract}

Keywords: work motivation, centre for learning activities program.

\section{PENDAHULUAN}

Sanggar Kegiatan Belajar (SKB) merupakan salah satu wadah yang memberikan pelayanan pendidikan kepada masyarakat melalui jalur Pendidikan Luar Sekolah (PLS). Peran PLS adalah penting dalam peningkatan mutu SDM. Di samping merupakan suatu kebanggaan dan penghargan, juga merupakan tantangan bagi para pengelolanya untuk dapat merealisasikan kepercayaan yang diberikan itu. Tantangan tersebut harus mendapat perhatian serius, bukan hanya karena tugas yang diemban adalah sangat penting dan mulia tetapi juga karena masih adanya berbagai kendala dalam pengelolaan PLS.

Memperhatikan hal tersebut, timbullah pertanyaan apakah pengelola satuan PLS menyadari tantangan dan tanggung jawab yang diembannya tersebut? Apakah mereka telah benar-benar serius dan dengan penuh dedikasi melaksanakan tugas dan kewajibannnya serta mempunyai komitmen profesional untuk meningkatkan mutu pendidikan? Pertanyaan tersebut juga berlaku dan tidak terkecuali bagi Sanggar Kegiatan Belajar (SKB) Lubuk Begalung yang merupakan unit pelaksana teknis Dinas Pendidikan Kota Padang.

\footnotetext{
* Pamong Belajar SKB Lb. Begalung Kota Padang 94 Jurnal IImiah VISI PTK-PNF - Vol. 2, No.1 - 2007
}

SKB Lubuk Begalung, Kota Padang, bertugas melakukan pembuatan percontohan dan pengendalian mutu pelaksanaan program pendidikan luar sekolah. Untuk melaksanakan tugas pokok tersebut, SKB mempunyai fungsi melakukan urusan tata usaha sanggar, melakukan pengelolaan, bimbingan dan penyuluhan kepada warga belajar tentang program percontohan serta melakukan pemantauan dan evaluasi program bimbingan dan penyuluhan, motivasi serta pengendalian mutu pendidikan luar sekolah dan pemuda.

Sebagai perangkat pelaksana dari tugas pokok dan fungsi di atas, SKB mempunyai susunan organisasi yang terdiri atas kepala, petugas administrasi dan petugas teknis operasional lapangan yang disebut dengan pamong belajar. Petugas administrasi dan pamong belajar merupakan unsur staf yang dalam melaksanakan tugasnya berada di bawah dan bertanggung jawab kepada kepala SKB (SK. Walikota Padang No. 54 tahun 2001, bab Il pasal 5).

Pamong belajar dan tenaga administrasi merupakan satu kesatuan yang integral dan saling menunjang satu sama lainnya.

Berdasarkan grand tour pada SKB Lubuk Begalung ditemukan situasi dan kondisi sebagai berikut. 
(1) Staf SKB Lubuk Begalung berjumlah 16 orang dengan perincian, tenaga administrasi sebanyak 4 orang dan pamong belajar sebanyak 12 orang, baik tenaga administrasi maupun pamong belajar seluruhnya merupakan pegawai negeri sipil, dan (2) latar belakang pendidikan mereka adalah berasal dari SLTA dan perguruan tinggi.

Selanjutnya juga ditemukan keadaan seperti berikut. (1) Staf SKB sering tidak masuk kerja, kalaupun datang sering terlambat dan pulang lebih cepat dari jam yang ditentukan; (2) banyak di antara staf yang bersikap tidak peduli dengan pekerjaan dan hanya menghabiskan waktu dengan membaca koran, dudukduduk dan bercerita membahas hal-hal yang tidak berhubungan dengan pekerjaan seperti masalah politik, olah raga bahkan masalah keluarga; (3) dalam menyelesaikan pekerjaan sepertinya staf tidak mempunyai target waktu yang jelas, kalaupun diberikan target penyelesaian pekerjaan sering terlambat dan kadang kala hasilnya kurang memuaskan; (4) adanya pamong belajar yang enggan dan merasa terpaksa untuk mengajar; (5) adanya keluhan staf tentang mekanisme dan pembagian kerja yang tidak jelas, transparansi anggaran, kepemimpinan kepala, hubungan antara staf yang kurang kondusif; (6)masih minimnya upaya yang dilakukan pamong belajar dalam mengatasi masalah-masalah pekerjaan dan cepat puas dengan kondisi yang ada; (7) beberapa orang di antara staf tampak cukup bersemangat dan mencurahkan perhatiannya terhadap pekerjaan dan ada pula yang sebaliknya; dan (8) adanya staf yang nampaknya bekerja namun mereka mengerjakan pekerjaan di luar tugas kantor seperti menyelesaikan tugas organisasi kemasyarakatan dan lain sebagainya.

Fenomena di atas memperlihatkan kecenderungan ke arah motivasi staf SKB yang kurang memuaskan dalam melaksanakan tugas atau pekerjaannya. Keadaan tersebut kalau dibiarkan dan tidak segera ditangani dengan baik, dikhawatirkan akan mempengaruhi pencapaian tujuan SKB. Kualitas pelayanan bukannya akan meningkat, akan tetapi sebaliknya akan terus menurun. Kondisi ini tentu saja akan mengecewakan banyak pihak.

Banyak penelitian tentang motivasi kerja telah dilakukan, namun baru sebatas untuk mengetahui seberapa jauh pengaruh dan dampak serta korelasi antara motivasi kerja dengan variabel lain secara kuantitatif. Oleh karena itu, perlu diketahui dan diungkapkan faktor-faktor yang melatar belakangi timbulnya perilaku tersebut melalui suatu penelitian alamiah tentang motivasi kerja staf khususnya pada SKB Lubuk Begalung.

Bertolak dari latar belakang masalah di atas, maka yang menjadi fokus penelitian ini adalah berkenaan dengan motivasi kerja staf SKB Lubuk Begalung dan faktor-faktor yang mempengaruhinya

\section{KAJIAN TEORI}

\section{Motivasi Kerja}

Motivasi kerja merupakan hal yang menarik dan penting untuk dibicarakan. Di samping sebagai salah satu dari fungsi manajemen, motivasi kerja juga adalah salah satu determinan penting bagi tampilan kinerja seseorang dan biasanya juga dihubungkan dengan produktifitas. Konsep motivasi dan upaya memotivasi bukan saja penting dan terjadi dalam dunia bisnis tetapi juga menjadi pembicaraan dalam segala bidang kehidupan.

Motivasi menurut Abizar (1988: 204) adalah seberapa besar seseorang individu secara personal berjanji dengan hati untuk berusaha semaksimal mungkin dalam menyelesaikan kegiatan atau tujuan tertentu. Lunenburg $(2000 ; 89)$ mengartikan motivasi dalam tiga hal, yaitu orang yang bekerja keras, orang yang tetap mempertahankan kerjanya, dan orang yang mengarahkan perilakunya untuk mencapai tujuan tertentu, yang meliputi tiga aspek umum dari motivasi yaitu usaha (effort), kegigihan (persistence) dan arahan (direction). Usaha berkaitan dengan intensitas perilaku staf. Kegigihan terkait dengan usaha yang dimanifestasikan dalam kegiatan yang berkaitan dengan pekerjaan dan arahan berkaitan dengan kualitas pekerjaan yang dilakukan staf.

Stephen P. Robbins (1996: 198) merumuskan motivasi sebagai kesediaan untuk mengeluarkan tingkat upaya yang tinggi ke arah tujuan organisasi, yang dikondisikan oleh kemampuan upaya itu untuk memenuhi sesuatu kebutuhan tertentu. Untuk meningkatkan prestasi kerja seseorang diperlukan rangsangan atau tenaga yang mendorong untuk berbuat. Proses pendorong meningkatkan prestasi kerja inilah yang dimaksud dengan motivasi kerja.

Kemudian Robbins juga menjelaskan bahwa motivasi adalah akibat dari interaksi individu dan situasi. Lebih lanjut Hersey dan Blanchard (1996: 16) menyatakan bahwa motivasi seseorang bergantung pada kuat lemahnya motif. Motif merupakan pendorong utama aktivitas. Motif ada kalanya diartikan sebagai 
kebutuhan, keinginan, dorongan, gerak hati dalam diri seseorang. Motif diarahkan pada tujuan yang mungkin berada pada alam bawah sadar. Motif adalah ikhwal mengapanya atau alasan di balik perilaku.

Dari pendapat-pendapat di atas dapat disimpulkan bahwa motivasi kerja staf merupakan semacam dorongan atau kekuatan yang terdapat pada diri seorang individu, sebagai hasil dari proses internal atau eksternal yang menjadi penyebab timbulnya tingkatan sikap dalam melaksanakan kegiatan atau pekerjaan, atau dengan kata lain motivasi dapat mendorong seseorang untuk berusaha keras demi mencapai tujuan, motivasi dapat juga menjadikan seseorang menyukai pekerjaannya dan mengarahkan seseorang untuk berperilaku yang baik seperti bersemangat, bertanggung jawab dan memiliki keseriusan dalam bekerja.

\section{METODE PENELITIAN}

Pengkajian tentang motivasi kerja pada dasarnya adalah berhubungan dengan perilaku seseorang untuk bekerja. Oleh sebab itu peneliti memilih metode kualitatif sebagai metode yang tepat untuk digunakan. Menurut Moleong (2004: 5) penelitian kualitatif merupakan penelitian yang memanfaatkan wawancara terbuka untuk menelaah dan memahami sikap, pandangan, perasaan dan perilaku individu atau sekelompok orang.

Berkaitan dengan itu Jane Richie dalam Moleong (2004: 6) menyatakan bahwasanya penelitian kualitatif adalah upaya untuk menyajikan dunia sosial dan perspektifnya di dalam dunia dari segi konsep, perilaku, persepsi tentang manusia yang diteliti. Lebih jauh Moleong menjelaskan bahwa penelitian kualitatif adalah penelitian yang bermaksud untuk memahami fenomena tentang apa yang dialami oleh subjek penelitian misalnya perilaku, persepsi, motivasi, tindakan dan lainlain secara holistik dan dengan cara deskripsi dalam bentuk kata-kata dan bahasa pada suatu konteks khusus yang alamiah dan dengan memanfaatkan berbagai metode alamiah.

Melalui penelitian ini diharapkan peneliti dapat menemukan latar belakang atau proses dari fenomena yang mempengaruhi motivasi kerja staf pada SKB Lubuk Begalung secara mendalam yang tidak dapat diteliti melalui penelitian kuantitatif.

Penelitian ini dilakukan dengan menggunakan langkah-langkah sebagaimana yang dikemukakan Bogdan dan Moleong yaitu (1) pra lapangan, (2) kegiatan lapangan, (3) melakukan analisis data, dan (4) menulis laporan penelitian.

Pada tahap pra lapangan ada beberapa kegiatan yang harus dilakukan peneliti seperti menyusun rancangan penelitian, memilih lapangan penelitian, mengurus perizinan, menjajaki dan menilai lapangan, memilih dan memanfaatkan informan serta menyiapkan perlengkapan penelitian.
Selanjutnya, melakukan kegiatan lapangan berupa observasi atau pengamatan. Observasi lapangan yang peneliti lakukan untuk penelitian ini adalah berupa grand tour dan mini tour. Grand tour merupakan observasi atau pengamatan yang dilakukan secara umum dan sebagai kelanjutannya dilakukan mini tour, yaitu observasi yang telah terfokus guna memperoleh data yang lebih terperinci.

Kegiatan ketiga yang dilakukan adalah proses analisis data yaitu menyangkut pelacakan, pengorganisasian, sintesis data dan pencarian pola serta penentuan hal-hal yang akan dilaporkan sesuai dengan fokus penelitian.

Analisis data dalam penelitian ini dilakukan secara berkelanjutan, terus menerus dan berulang selama proses pengumpulan data dan setelah pengumpulan data berakhir. Analisis data selama proses pengumpulan data dimaksudkan untuk mengumpulkan data yang ada serta memikirkan data baru yang akan dikumpulkan, mencari kebenaran informasi yang masih kabur dan mencek serta mengarahkan analisis yang sedang berjalan. Sedangkan analisis data setelah pengumpulan data pada prinsipnya adalah kelanjutan dari analisis sebelumnya, dalam hal ini peneliti melengkapi dan memaparkan data secara sistematis serta memastikan konsep atau pola yang telah dibangun berdasarkan data lapangan. Setelah melaksanakan analisis data secara kualitatif, tugas peneliti selanjutnya adalah menulis laporan penelitian.

Data yang diperlukan dalam penelitian ini diperoleh dengan menggunakan teknik observasi, wawancara dengan informan dan pengkajian dokumen. Sedangkan analisis data dilakukan dengan cara reduksi data, penyajian data, dan penarikan kesimpulan/ verifikasi, sebagaimana skema berikut. 




Gambar: Model analisis data

\section{HASIL PENELITIAN}

Temuan umum penelitian antara lain data tentang pamong belajar SKB mayoritas adalah perempuan, golongan mayoritas adalah golongan III dengan masa kerja lebih dari 9 tahun, pendidikan berimbang antara sarjana dan non sarjana (diploma/SLTA) sedangkan dari segi usia mayoritas pamong belajar berusia antara 4049 tahun.

Jumlah staf TU pada SKB antara laki-laki dan perempuan adalah sama, mayoritas mereka adalah golongan III, latar belakang pendidikan berimbang antara sarjana dan nonsarjana dan usia dengan interval yang bervariasi. Warga belajar yang belajar pada SKB berjumlah 463 orang, yang terdiri dari 358 orang lakilaki dan 105 orang perermpuan. Warga belajar tersebut tersebar pada 11 program/kelompok belajar dengan tempat belajar berada di SKB 8 kelompok dan di luar SKB (di masyarakat) 3 kelompok.

Temuan khusus penelitian diperoleh dari hasil wawancara dengan informan penelitian yaitu staf (pamong belajar dan tenaga administrasi) serta kepala SKB.

\section{Motivasi Staf SKB}

Berdasarkan observasi dan wawancara yang dilakukan, kemudian diolah dengan trianggulasi data, dapat diperoleh gambaran tentang motivasi kerja staf SKB Lubuk Begalung. Keadaan yang sering peneliti temukan berkaitan dengan kondisi kerja staf SKB tersebut adalah seperti kurangnya kedisiplinan, kurangnya kesungguhan dalam melaksanakan tugas, kurangnya antusiasme, inisiatif dan semangat kerja serta kurangnya tanggung jawab terhadap tugas.

Kondisi di atas ditemui hampir pada semua aspek pelaksanaan tugas dan fungsi staf seperti dalam pengelolaan program, pelaksanaan bimbingan dan penyuluhan, pemantauan dan evaluasi program, pelayanan informasi, pembuatan sarana belajar, pelaksanaan urusan kepegawaian, serta pengelolaan perpustakaan tidak dilaksanakan dengan baik. Petikan wawancara berikut dapat diperhatian : "Motivasi kerja staf di sini memang agak kurang, di mana mereka sepertinya tidak tahu dan tidak mau tahu dengan jobnya serta tidak melaksanakan tugas sesuai dengan tugas pokok dan fungsinya. Mereka itu dalam bekerja, kalau pekerjaan itu mendesak baru dikerjakan dan cepat berpuas diri dengan keadaan yang ada (Ka.SKB)". Wawancara dengan penjaga kantor menyatakan: "Orang SKB datang ke kantor memang agak siang, bahkan ada yang datang pukul 10.30. Kalau ada orang yang mau berurusan jadi lama menunggu, kadang orang yang ditunggu itupun tidak datang".

Faktor-faktor yang mempengaruhi motivasi kerja staf SKB Lubuk Begalung

Penelitian ini memperlihatkan beberapa temuan khusus terkait faktor yang mempengaruhi motivasi staf. 1. Suasana kerja yang kurang kondusif.

Suasana kerja yang kurang kondusif terlihat dari kondisi kerja dan hubungan yang tidak intim/ harmonis di antara sesama staf serta antara staf 
dengan kepala. Hal ini terlihat dari ketidakseriusan staf dalam bekerja misalnya dalam menangani berbagai masalah yang terdapat pada kelompok belajar seperti rendahnya angka kehadiran warga belajar, masalah disiplin dan tata krama/akhlak warga belajar sebagai pelajar, sikap warga belajar dalam belajar dan sebagainya. Hubungan kurang harmonis antara lain terungkap sebagaimana petikan wawancara dengan staf administrasi berikut: "Memang betul, saya tidak senang dengan Ibu itu, kalau memarahi di sembarang tempat saja, maunya dipanggil, kalau salah diajari, dikasih tahu yang benarnya".

2. Kepemimpinan Kepala SKB

Berdasarkan observasi dan wawancara yang dilakukan, kemudian diolah dengan trianggulasi data terlihat bahwa rendahnya motivasi kerja staf SKB Lubuk Begalung juga dipengaruhi oleh kepemimpinan Kepala. Dalam periode penelitian ini terdapat pergantian kepala SKB, dan terhadap keduanya dilakukan pengambilan data. Sesuai dengan hasil observasi dan wawancara, terungkap bahwa motivasi kerja staf membaik setelah terjadinya pergantian Kepala SKB. Salah satunya adalah faktor kepemimpinan Kepala yang menimbulkan simpati staf terhadap sikap Kepala tersebut.

3. Ketidakjelasan sanksi bagi yang tidak melaksanakan tugas

Salah satu petikan wawancara berikut ini memperlihatkan faktor ini. "Kalau teguran tertulis pakai surat tidak pernah, dipanggil khusus untuk menanyakan kenapa tidak datang juga tidak pernah. Kalau ditelepon saya pernah, karena ada pekerjaan yang harus saya selesaikan".
4. Motif uang (imbalan material)

Berdasarkan pengamatan yang peneliti lakukan terlihat bahwa dalam melaksanakan pekerjaan staf SKB sepertinya lebih cenderung mementingkan pekerjaan atau kegiatan yang mendatangkan keuntungan material. Hal ini terlihat misalnya pada saat pelaksanaan ujian persamaan (kesetaraan bagi mereka yang tidak memiliki ijazah SD, SLTP dan SLTA). Pada kesempatan itu, staf yang telah ditunjuk sebagai panitia tampaknya benar-benar melaksanakan tugas tersebut dengan baik. Dikatakan, ujian persamaan ini lebih mendatangkan keuntungan material bagi staf adalah karena honor yang didapatkan dari kegiatan ini lebih besar dari kegiatan SKB lainnya, sebagaimana disampaikan koordinator pamong belajar.

Dari keempat faktor penyebab motivasi kerja staf SKB Lubuk Begalung terlihat kecenderungan kepada faktor kepemimpinan (leadership). Hal ini mengingat bahwa suasana kerja di luar faktor fasilitas kerja (relatif sudah memadai), tidak adanya sanksi, faktor imbalan, ternyata memang faktor pimpinan sangat dominan. Oleh karena itu, merujuk kepada pendapat Sondang P Siagian (2003: 30) yang menyatakan bahwa kepemimpinan (leadership) merupakan inti daripada manajemen karena kepemimpinan merupakan motor penggerak bagi sumber-sumber dan alat-alat serta manusia dalam suatu organisasi.

Demikian pentingnya peranan kepemimpinan dalam usaha mencapai tujuan suatu organisasi sehingga dapat dikatakan bahwa sukses atau kegagalan yang dialami oleh organisasi sebagian besar ditentukan oleh kualitas kepemimpinan yang dimiliki oleh orang-orang yang diserahi tugas mempimpin dalam organisasi itu.

\section{KESIMPULAN}

Dari hasil penelitian yang telah dilakukan, maka dapat diambil beberapa kesimpulan sebagai berikut :

1. Motivasi staf SKB Lubuk Begalung, Kota Padang, pada umumnya kurang baik (rendah) dalam melaksanakan tugas dan fungsinya.

2. Faktor-faktor yang mempengaruhi rendahnya motivasi kerja staf tersebut adalah :

a. Suasana kerja yang kurang kondusif akibat kurang baik/harmonisnya hubungan antara sesama staf dan antara staf dengan Kepala.

b. Kepemimpinan Kepala SKB dalam hal pembagian kerja tidak jelas dan tidak merata, kurangnya kematangan emosional, tidak konsisten dengan keputusan yang diambil (suka berubah-ubah) dan tidak adanya penjelasan bila terjadi perubahan dalam pembagian kerja.

c. Ketidakjelasan sanksi bagi staf yang tidak melaksanakan tugas

d. Motif uang atau masalah besar kecilnya materil yang diterima.

3. Upaya yang telah dilakukan Kepala SKB untuk memotivasi stafnya dalam bekerja menurut Kepala SKB adalah dengan memberi pengarahan dan teguran pada staf serta memberikan sanksi. Namun demikian berdasarkan pengamatan dan pengakuan staf dalam wawancara, upaya tersebut tidak 
sepenuhnya dilakukan, bahkan beberapa upaya yang oleh Kepala SKB dianggap sebagai hal yang memotivasi justru sebaliknya menimbulkan ketidakpuasan. Hal ini terlihat dari banyaknya keluhan-keluhan yang diungkapkan para staf

4. Adapun upaya yang perlu dilakukan dalam rangka menjaga, memperbaiki dan meningkatkan motivasi kerja staf SKB, terutama oleh Kepala SKB sebagai pimpinan dan penggerak organisasi adalah sebagai berikut.

a. Memberi penjelasan tujuan organisasi dan tujuan setiap kegiatan yang akan dilaksanakan kepada semua staf.

b. Mengusahakan agar setiap staf menyadari, memahami serta menerima baik tujuan tersebut.

c. Menjelaskan/mendiskusikan metode yang digunakan dalam menjalankan kegiatan serta kebijakan yang ditempuh oleh Kepala dalam usaha pencapaian tujuan.

d. Mengusahakan agar setiap staf mengerti struktur organisasi dan tata kerja serta menjelaskan peranan apa yang diharapkan untuk dijalankan setiap staf.

e. Mengupayakan agar para staf mendapatkan informasi umpan balik (feed back) tentang bagaimana hasil kerja mereka.

f. Menekankan pentingnya kerjasama antar staf dan dengan kepala dalam melaksanakan kegiatan.

g. Menciptakan suasana yang menyenangkan, saling terbuka atau adanya tranparansi dan saling percaya.

h. Memberikan penghargaan (reward/imbalan atau insentif yang sesuai serta pujian) kepada staf yang cakap, teguran dan sanksi serta bimbingan kepada staf yang kurang mampu bekerja.

i. Memperlakukan staf dengan sentuhan manusiawi.

j. Merangkul, mengajak staf bekerja untuk kepentingan sendiri dan kemaslahatan organisasi serta menumbuhkembangkan rasa memiliki.

\section{DAFTAR PUSTAKA}

Abizar. (1988). Komunikasi organisasi. Jakarta: Depdiknas, P2LPTK.

Boqdan, R. \& Biklen, S. K. (1982). Qualitative research for education: An introduction to theory and method. Boston: Allyn and Bacon.

Chaedar A. A. (2002). Pokoknya kualitatif: Dasar-dasar merancang dan melakukan penelitian kualitatif. Jakarta: PT. Dunia Pustaka Jaya.

Fremont, K. E. \& Rosenzweig, J. (1990). Organization and management (Penerjemah: A. Hasymi Ali). Jakarta: Bumi Aksara.

Lunenburg, F. C \& Alland. (2000). Educational administration: Concept and practices. (3rd Ed). Stanford USA: Wardsworth Thomson Learning.

Moleong, L. J. (2004). Metodologi penelitian kualitatif. Bandung: PT. Remaja Rosdakarya.

Mukhaiyar, dkk. (2004). Buku panduan penulisan tesis dan disertasi. UNP: PPS

Pemerintah Kota Padang. (2001). SK. Nomor : 54 Tahun 2001 Tentang Rincian Tugas Pokok Unit Pelaksana Teknis Dinas Sanggar Kegiatan Belajar. Padang.
Ramidjo. (2001). Kebijakan dan program pembangunan Pendidikan Luar Sekolah (PLS). Padang: Pemda Sumatera Barat.

Rohendi T. R. (1992). Analisis data kualitatif (Terjemahan). Jakarta: Universitas Indonesia.

Siagian, S. P. (2003). Filsafat administrasi. Jakarta: Bumi Aksara.

SKB Lubuk Begalung-Kota Padang. (2000). Profil SKB Lubuk Begalung Kota Padang dalam melaksanakan program percontohan Pendidikan Luar Sekolah, Pemuda, dan Olah Raga di Kota Padang. Padang : SKB Lb. Begalung

Spradley, S. P. (1980). Participant observation. New York: Halt Rinehart and Winston.

Danim, S. (2002). Menjadi peneliti kualitatif. Bandung: CV. Pustaka Setia.

(2003).Undang-Undang No. 20 tahun 2003 tentang Sistem Pendidikan Nasional. Jakarta.

Winardi. (2004). Motivasi dan pemotivasian dalam manajemen. Jakarta: PT. Raja Grafindo Persada. 